\title{
Promising Cd-free double buffer layer in CZTSSe thin film solar cells
}

\author{
Siyu Wang ${ }^{1}$, Zhenwu Jiang ${ }^{1}$, Zhan Shen ${ }^{1}$, Yali Sun ${ }^{1}$, Hongling Guo ${ }^{1}$, Li Wu ${ }^{2}$, Jianjun Zhang ${ }^{1}$, \\ Jianping Ao ${ }^{1}$, Hai Wang ${ }^{3}$ and Yi Zhang ${ }^{1 *}$
}

\begin{abstract}
Zn}(\mathrm{O}, \mathrm{S})$ film is widely used as a Cd-free buffer layer for kesterite thin film solar cells due to its low-cost and eco-friendly characteristics. However, the low carrier concentration and conductivity of $\mathrm{Zn}(\mathrm{O}, \mathrm{S})$ will deteriorate the device performance. In this work, an additional buffer layer of $\mathrm{In}_{2} \mathrm{~S}_{3}$ is introduced to modify the properties of the $\mathrm{Zn}(\mathrm{O}, \mathrm{S})$ layer as well as the CZTSSe layer via a post-annealing treatment. The carrier concentrations of both the $\mathrm{Zn}(0, S)$ and CZTSSe layers are increased, which facilitates the carrier separation and increases the open circuit voltage $\left(V_{O C}\right)$. It is also found that ammonia etching treatment can remove the contamination and reduce the interface defects, and there is an increase of the surface roughness of the $\operatorname{In}_{2} S_{3}$ layer, which works as an antireflection layer. Consequently, the efficiency of the CZTSSe solar cells is improved by $24 \%$ after the annealing and etching treatments. Simulation and experimental results show that a large band offset of the $\operatorname{In}_{2} S_{3}$ layer and defect energy levels in the $\mathrm{Zn}(\mathrm{O}, \mathrm{S})$ layer are the main properties limiting the fill factor and efficiency of these CZTSSe devices. This study affords a new perspective for the carrier concentration enhancement of the absorber and buffer layers by In-doping, and it also indicates that $\operatorname{In}_{2} \mathrm{~S}_{3} / \mathrm{Zn}(\mathrm{O}, \mathrm{S})$ is a promising Cd-free hybrid buffer layer for high-efficiency kesterite solar cells.
\end{abstract}

Keywords: double buffer layer, CZTSSe, In-doping, band offset

\section{INTRODUCTION}

In recent years, $\mathrm{Cu}_{2} \mathrm{ZnSn}(\mathrm{S}, \mathrm{Se})_{4}$ (CZTSSe) has been regarded as a promising absorber material due to its merits and promising photovoltaic performance compared with that of $\mathrm{Cu}(\mathrm{In}, \mathrm{Ga}) \mathrm{Se}_{2}$ (CIGS) [1-6]. To date, over-11\%efficient CZTSSe solar cells using CdS layer as the buffer layer have been reported [7-9]. The application of a CdS buffer layer in CZTSSe solar cells enables good efficiency due to the appropriate conduction band offset (CBO) at the CdS and CZTSSe heterojunction $[10,11]$. However, the toxic and hazardous cadmium in CdS buffer layers remains a serious problem [12].

To solve this problem, Cd-free buffer layers, such as ( $\mathrm{Zn}, \mathrm{Mg}) \mathrm{O}, \mathrm{Zn}(\mathrm{O}, \mathrm{S})$, and $\mathrm{Zn}_{1-x} \mathrm{Sn}_{x} \mathrm{O}$ (ZTO), have been proposed to replace the CdS layer [13-15]. Among those Cd-free buffer layers, the $\mathrm{Zn}(\mathrm{O}, \mathrm{S})$ buffer layer has been widely studied due to its controllable bandgap, low-cost, and low-toxicity characteristics. Recently, many groups have demonstrated over-5\% CZTSSe solar cells using $\mathrm{Zn}(\mathrm{O}, \mathrm{S})$ as a buffer layer [16,17]. Neuschitzer et al. [18] reported a 6.5\%-efficient CZTSe solar cell with a $10-\mathrm{nm}$ thick $\mathrm{Zn}(\mathrm{O}, \mathrm{S})$ buffer layer by adjusting the sulfur content in the $\mathrm{Zn}(\mathrm{O}, \mathrm{S})$ buffer layer. However, making an excessively thin $\mathrm{Zn}(\mathrm{O}, \mathrm{S})$ buffer layer with uniform coverage remains an unsolved problem. In order to improve the coverage of the $\mathrm{Zn}(\mathrm{O}, \mathrm{S})$ buffer layer at the junction interface, our group [19] reported a 7.2\%-efficient CZTSSe solar cell with 25 -nm-thick $\mathrm{Zn}(\mathrm{O}, \mathrm{S})$ as the buffer layer (with an anti-reflectivity layer). The CZTSSe solar cell with a $\mathrm{Zn}(\mathrm{O}, \mathrm{S})$ buffer layer has good performance, but the low carrier concentration and low conductivity of the $\mathrm{Zn}(\mathrm{O}, \mathrm{S})$ layer can increase the contact resistance and reduce the carrier collection efficiency, and thus the performance of the device is deteriorated [20,21]. Therefore, it is necessary to find a way to increase the carrier concentration and conductivity of the $\mathrm{Zn}(\mathrm{O}, \mathrm{S})$ layer.

Herein, we deposited a thin $\operatorname{In}_{2} \mathrm{~S}_{3}$ layer on $\mathrm{Zn}(\mathrm{O}, \mathrm{S}) /$ CZTSSe/Mo. After annealing at low temperature, the

\footnotetext{
${ }^{1}$ Institute of Photoelectronic Thin Film Devices and Technology, Tianjin Key Laboratory of Thin Film Devices and Technology, Nankai University, Tianjin 300350, China

${ }^{2}$ The Key Laboratory of Weak-Light Nonlinear Photonics, Ministry of Education, School of Physics, Nankai University, Tianjin 300071, China

${ }^{3}$ College of Electronic Information and Optical Engineering, Nankai University, Tianjin 300350, China

* Corresponding author (email: yizhang@nankai.edu.cn)
} 
buffer layer was etched by concentrated ammonia. It is found that indium diffuses into the $\mathrm{Zn}(\mathrm{O}, \mathrm{S})$ layer as well as the CZTSSe layer during the annealing treatment, which increased the carrier concentration of both the absorber and buffer layers. The concentrated ammonia can remove the contaminants at the interface and enhance the light absorption by increasing the surface roughness of the $\operatorname{In}_{2} \mathrm{~S}_{3}$ layer. After the treatments, both the open circuit voltage $\left(V_{\mathrm{OC}}\right)$ and short-circuit current density $\left(J_{\mathrm{SC}}\right)$ of CZTSSe solar cells were improved, and, as a result, the efficiency of the CZTSSe solar cells was improved by $24 \%$. Subsequently, simulation was employed to understand the limitations of $\operatorname{In}_{2} \mathrm{~S}_{3} / \mathrm{Zn}(\mathrm{O}, \mathrm{S}) /$ CZTSSe solar cell efficiency taking into account the interface between $\mathrm{In}_{2} \mathrm{~S}_{3}$ and $\mathrm{Zn}(\mathrm{O}, \mathrm{S})$.

\section{EXPERIMENTAL SECTION}

\section{Preparation of films and solar cells}

CZTSSe absorbers were fabricated by sol-gel and then a selenization process. The detailed fabrication process was described in Ref. [22]. Next, the $\mathrm{Zn}(\mathrm{O}, \mathrm{S})$ layers were deposited on the CZTSSe absorbers using the chemical bath deposition (CBD). The preparation process of the $\mathrm{Zn}(\mathrm{O}, \mathrm{S})$ was described in Ref. [21]. The $\operatorname{In}_{2} \mathrm{~S}_{3}$ layers were spin-coated onto the samples at $2000 \mathrm{r} \mathrm{min}^{-1}$ for $20 \mathrm{~s}$ and then dried. The $\operatorname{In}_{2} \mathrm{~S}_{3}$ solution was prepared by dissolving $1.1 \mathrm{~g} \mathrm{In}_{2} \mathrm{~S}_{3}$ and $0.38 \mathrm{~g}$ thiourea into $10 \mathrm{~mL}$ 2-methoxyethanol (AR). The $\mathrm{In}_{2} \mathrm{~S}_{3}$ layers underwent the optimal annealing treatment in $\mathrm{Ar}$ atmosphere at $280^{\circ} \mathrm{C}$ for $5 \mathrm{~min}$. Subsequently, the samples were etched by $25 \%-28 \%$ concentrated ammonia for $5 \mathrm{~min}$ followed by rinsing in deionized (DI) water. The CZTSSe solar cell fabrication was finished with the sputtering of a 500-nm $\mathrm{ZnO}: \mathrm{Al}$ layer and evaporated $\mathrm{Ni} / \mathrm{Al}$ grid contacts. The active area of each CZTSSe solar cell was $0.34 \mathrm{~cm}^{2}$.

\section{Characterization}

A PANalytical X'Pert PRO X-ray diffractometer (XRD) was used to measure the crystal structures with $\mathrm{Cu} \mathrm{Ka}$ as the radiation source. The morphologies of the films were measured using a Hitachi S-4800 scanning electron microscope (SEM). Atomic force microscope (AFM) on a Dimension Icon (Bruker) was used to measure the surface morphology and roughness of these films over an area of $25 \mu \mathrm{m}^{2}$. The current density-voltage $(J-V)$ characteristics of the solar cells were measured under a solar simulator at room temperature (RT) with the illumination intensity of $1000 \mathrm{~W} \mathrm{~m}^{-2}$ and the standard AM 1.5 spectrum. The surface chemical compositions of the films were char- acterized by X-ray photoelectron spectroscopy (XPS, ESCALAB 250Xi, Thermo Scientific) with $\mathrm{Al} \mathrm{Ka}$ as the Xray source. Raman measurement was performed to characterize the surface phases of the films with an excition wavelength of $514 \mathrm{~nm}$. The carrier density profiles of these solar cells were measured by the capacitancevoltage $(C-V)$ technique with a $100-\mathrm{kHz}$ alternating current (AC) excitation source and a direct current (DC) bias from 0.5 to $-1 \mathrm{~V}$. A chopped white light source was used to measure the external quantum efficiency (EQE) spectra on a system calibrated using a certified $\mathrm{Si}$ solar cell and InGaAs solar cell. The bandgap of $\operatorname{In}_{2} \mathrm{~S}_{3}$ was calculated from the transmittance and reflection spectra, which were measured with a Varian Cary 5000 UV-Vis-NIR Spectrophotometer between 200 and $2000 \mathrm{~nm}$.

\section{RESULTS AND DISCUSSION}

\section{Annealing and ammonia etching treatments on the $\operatorname{In}_{2} S_{3}$ thin films}

To study the effect of annealing and ammonia etching treatments on the $\operatorname{In}_{2} \mathrm{~S}_{3}$ films, XRD, SEM, and AFM were used to measure the $\mathrm{In}_{2} \mathrm{~S}_{3}$ films. The $\mathrm{In}_{2} \mathrm{~S}_{3}$ films are polycrystalline and grow with a (103) preferred orientation for the as-grown (reference) sample and the samples annealed at 280,330 and $380^{\circ} \mathrm{C}$, as shown in Fig. S1. The intensity of the (103) peak of the $\operatorname{In}_{2} \mathrm{~S}_{3}$ film annealed at $280^{\circ} \mathrm{C}$ is the strongest. SEM images of the surfaces of the annealed $\operatorname{In}_{2} \mathrm{~S}_{3}$ films are shown in Fig. S2a-d. The images indicate that the surface morphology of $\operatorname{In}_{2} \mathrm{~S}_{3}$ films is not significantly changed after annealing. However, the grain size of the $\operatorname{In}_{2} \mathrm{~S}_{3}$ layer annealed at $280^{\circ} \mathrm{C}$ is larger than those of the $\mathrm{In}_{2} \mathrm{~S}_{3}$ films with other annealing temperatures, as seen in the cross-sectional images in Fig. S2e-h, and this is consistent with the XRD results.

After the $280^{\circ} \mathrm{C}$ annealing treatment, we soaked the samples in the concentrated ammonia solution for 0,3 and $5 \mathrm{~min}$. AFM images of the $\operatorname{In}_{2} \mathrm{~S}_{3}$ layers shown in Fig. 1 indicate that the $\mathrm{Ra}$ (arithmetic average of the absolute roughness) values of the samples etched in concentrated ammonia for 0,3 and $5 \mathrm{~min}$ are 16.1, 18.1 and $21.4 \mathrm{~nm}$, respectively. Fig. S3 shows the reflectance spectra of $\operatorname{In}_{2} \mathrm{~S}_{3}$ films etched by the concentrated ammonia for 0,3 and $5 \mathrm{~min}$. The reflectance of the samples decreases with the etching time increasing. These results mean that the ammonia etching treatment can effectively increase the surface roughness of the $\operatorname{In}_{2} \mathrm{~S}_{3}$ layer, which can reduce the reflectance losses in the films and enhance the light trapping. Thus, the performance of $\mathrm{In}_{2} \mathrm{~S}_{3}$ films should be best after annealing at $280^{\circ} \mathrm{C}$ followed by a 
5-min concentrated ammonia etching treatment.

Device performance after annealing and ammonia etching treatments

In this work, we analyzed three groups of $\operatorname{In}_{2} \mathrm{~S}_{3} / \mathrm{Zn}(\mathrm{O}, \mathrm{S}) /$ CZTSSe solar cells with different interface treatments. All the CZTSSe absorbers and $\mathrm{Zn}(\mathrm{O}, \mathrm{S})$ buffer layers were fabricated by the same process. In the first group, the $\mathrm{In}_{2} \mathrm{~S}_{3}$ films without treatment (Sample Reference) were deposited on the $\mathrm{Zn}(\mathrm{O}, \mathrm{S}) / \mathrm{CZTSSe}$ films. In the second group, the $\operatorname{In}_{2} \mathrm{~S}_{3}$ films were deposited on the $\mathrm{Zn}(\mathrm{O}, \mathrm{S})$ / CZTSSe films and then the samples were annealed at $280^{\circ} \mathrm{C}$ (Sample Annealed). In the third group, the $\operatorname{In}_{2} \mathrm{~S}_{3}$ films were deposited on the $\mathrm{Zn}(\mathrm{O}, \mathrm{S}) / \mathrm{CZTSSe}$ films and then the samples were annealed at $280^{\circ} \mathrm{C}$ followed by the concentrated ammonia etching for $5 \mathrm{~min}$ (Sample Annealed\&Etched). The CZTSSe solar cells were fabricated using the Sample Reference, Sample Annealed, and
Sample Annealed\&Etched as the absorber layers. The corresponding solar cells are denoted as Cell Reference, Cell Annealed, and Cell Annealed\&Etched.

Fig. 2a presents the $J-V$ curves of the Cell Reference, Cell Annealed, and Cell Annealed\&Etched devices. The photovoltaic parameters of these devices are listed in Table 1 . The $V_{\mathrm{OC}}$ and $J_{\mathrm{SC}}$ of the Cell Annealed and Cell Annealed\&Etched devices are higher than those of the Cell Reference. The fill factors (FF) of Cell Annealed and Cell Annealed\&Etched are higher than that of Cell Reference, which is attributed to both lower ideality factor $(A)$ and reverse saturation current density $\left(J_{0}\right)$ extracted from the $J-V$ curves, as shown in Fig. 2b, c. This indicates that the interface recombination is inhibited, which will also be proved below. As a result, after the annealing and etching treatments, the $V_{\mathrm{OC}}$ and $J_{\mathrm{SC}}$ of the CZTSSe solar cells are improved, and, as a result, the efficiency of the CZTSSe solar cell is improved by $24 \%$.
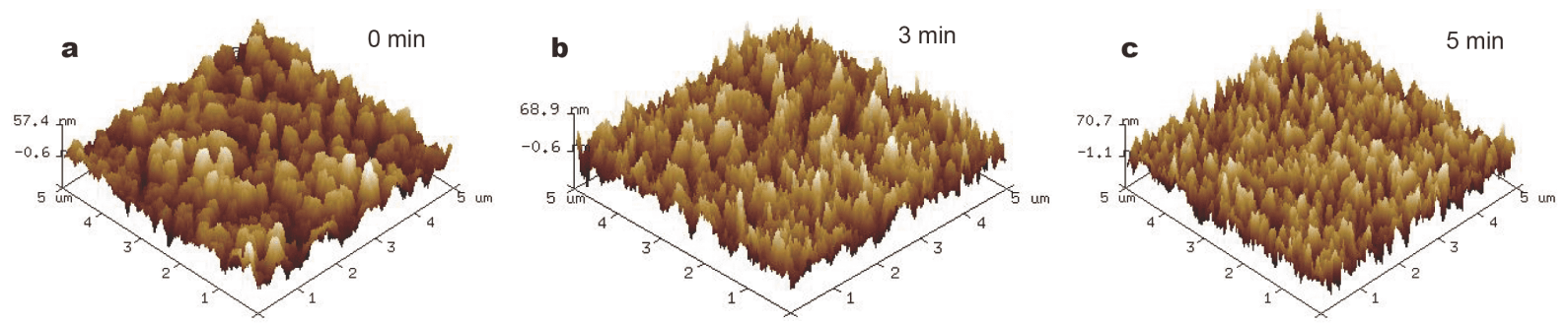

Figure 1 AFM topography images of $\operatorname{In}_{2} \mathrm{~S}_{3}$ films with the ammonia etching for (a) 0, (b) 3 and (c) 5 min.
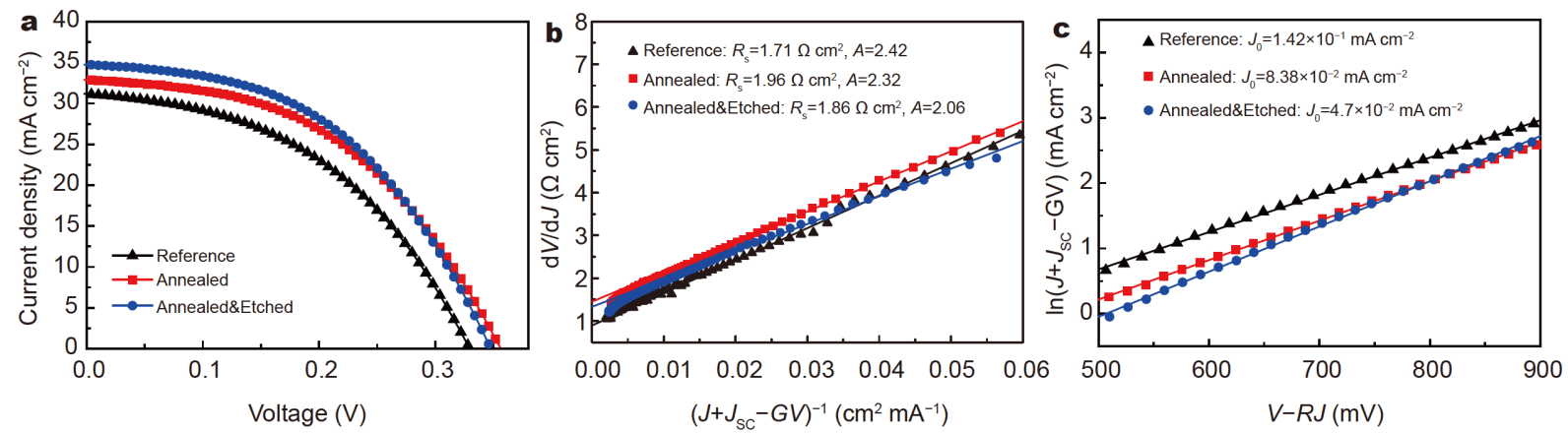

Figure 2 (a) The $J-V$ curves of Cell Reference, Cell Annealed, and Cell Annealed\&Etched. (b) The $R_{\mathrm{s}}$, $A$, and (c) the $J_{0}$ of Cell Reference, Cell Annealed, and Cell Annealed\&Etched from fitting with light $J-V$ curves. $G$ in (b) is shunt conductance.

Table 1 The photovoltaic parameters of the representative Cell Reference, Cell Annealed, and Cell Annealed\&Etched devices

\begin{tabular}{cccccccc}
\hline Cell & $V_{\mathrm{OC}}(\mathrm{mV})$ & $J_{\mathrm{SC}}\left(\mathrm{mA} \mathrm{cm}^{-2}\right)$ & $\mathrm{FF}(\%)$ & $\eta(\%)$ & $R_{\mathrm{s}}\left(\Omega \mathrm{cm}^{2}\right)$ & $A$ & $J_{0}\left(\mathrm{~mA} \mathrm{~cm}^{-2}\right)$ \\
\hline Reference & 328 & 31.18 & 45.28 & 4.63 & 1.71 & 2.42 & $1.42 \times 10^{-1}$ \\
Annealed & 358 & 32.89 & 46.72 & 5.50 & 1.96 & 2.32 & $8.38 \times 10^{-2}$ \\
Annealed\&Etched & 346 & 34.76 & 47.80 & 5.75 & 1.86 & 2.06 & $4.70 \times 10^{-2}$ \\
\hline
\end{tabular}


To investigate the reason why the device performance changes after the heterojunction interface treatments, the quality of the $\operatorname{In}_{2} \mathrm{~S}_{3} / \mathrm{Zn}(\mathrm{O}, \mathrm{S}) / \mathrm{CZTSSe}$ interfaces was characterized firstly. Fig. $3 a-c$ show the surface SEM images of Sample Reference, Sample Annealed, and Sample Annealed\&Etched. It is obvious that the fabricated $\operatorname{In}_{2} \mathrm{~S}_{3} / \mathrm{Zn}(\mathrm{O}, \mathrm{S})$ hybrid buffer layers formed with uniform and dense coverage on the absorbers. The grains and grain boundaries of Sample Annealed are clear, and the thickness of the buffer layer of Sample Annealed is thinner than that of Sample Reference, which can be ascribed to the elemental inter-diffusion caused by the annealing treatment. Additionally, the crystallization and the coverage of the buffer layer are improved by the annealing treatment, which improves both the $V_{\mathrm{OC}}$ and FF; however, extra clusters at the surface of the buffer layer, which formed during the annealing treatment, will lead to an increase of interfacial recombination at the CZTSSe/ AZO interface and a corresponding increase of the series resistance $\left(R_{\mathrm{S}}\right)$ [23]. The clusters are removed effectively by the concentrated ammonia etching treatment, which will thus improve the contact of the CZTSSe/AZO interface and result in a decrease of $A$ and $J_{0}$. Fig. $3 d-f$ show the cross-sectional morphologies of Sample Reference, Sample Annealed, and Sample Annealed\&Etched. It is clear that the hybrid buffer layers can be well-preserved on the top of the absorbers after the series of post-treatments.

Fig. $4 a-c$ show the S 2p/Se 3p XPS spectra of Sample Reference, Sample Annealed, and Sample Annealed\&Etched. From Fig. 4 and Fig. S4, the locations of the $S 2 p$ peak and In $3 d$ peak indicate that the indium bonds to the sulfur atom and forms $\operatorname{In}_{2} S_{3}$ phases [24]. On the other hand, the peaks at 159.9 and $166.29 \mathrm{eV}$ belong to Se $3 p_{3 / 2}$ and Se $3 p_{1 / 2}$ (Fig. 4) [25-27]. Comparing the in-

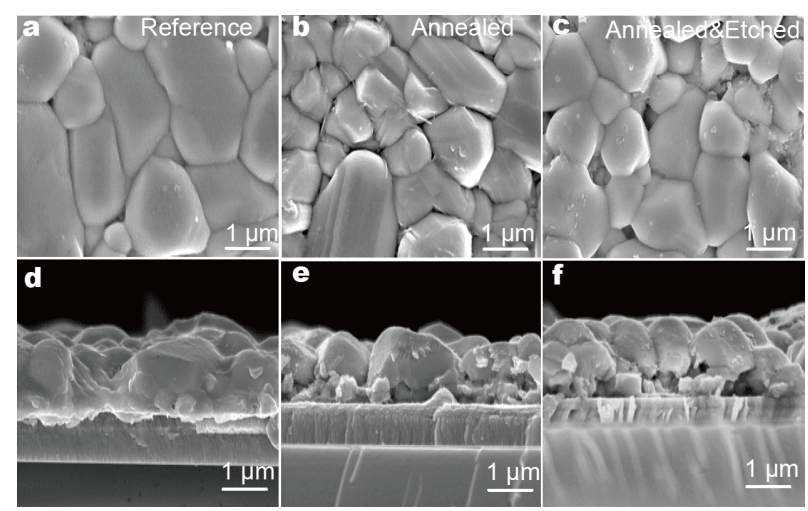

Figure 3 The $(\mathrm{a}-\mathrm{c})$ surface and $(\mathrm{d}-\mathrm{f})$ cross-sectional SEM images of Sample Reference, Sample Annealed, and Sample Annealed\&Etched. tensity of the Se $3 p$ peaks shown in Fig. $4 a, b$, the increase of the Se 3 p peak intensity in Fig. $4 \mathrm{~b}$ indicates that a lot of selenium from the CZTSSe diffuses into the $\operatorname{In}_{2} \mathrm{~S}_{3}$ and the $\mathrm{Zn}(\mathrm{O}, \mathrm{S})$ during the annealing treatment. The thickness of the $\mathrm{In}_{2} \mathrm{~S}_{3}$ layer is reduced after the sample is annealed and then etched in concentrated ammonia solution. X-rays can penetrate the absorber layer deeply, thus the intensity of the Se $3 p$ peak is enhanced dramatically (Fig. 4c). Similarly, the indium should also diffuse into the $\mathrm{Zn}(\mathrm{O}, \mathrm{S})$ and CZTSSe layers. To prove that the indium diffuses into the $\mathrm{Zn}(\mathrm{O}, \mathrm{S})$ and CZTSSe layers, Raman spectra are also collected and shown in Fig. 5. The Raman spectra of all samples show strong Raman peaks at 172, 196 and $238 \mathrm{~cm}^{-1}$, which is consistent with the Raman peaks of CZTSe in previous reports [28-30]. The Raman peak at $250 \mathrm{~cm}^{-1}$ belongs to the $\mathrm{ZnSe}$ phase. The intensity of the Raman peak at $172 \mathrm{~cm}^{-1}$ for Sample Annealed\&Etched is decreased and the intensity of its peak at $250 \mathrm{~cm}^{-1}$ is increased compared with Sample Reference, which proves a decrease of $\mathrm{Cu}$ and an increase of $\mathrm{Zn}$ after annealing treatment. In addition, the Raman peaks of Sample Annealed\&Etched at 172 and $196 \mathrm{~cm}^{-1}$ shift toward lower wave number compared with Sample Reference. The shift of the Raman peaks is due to the smaller Sn ions (0.69 $\AA$ ) substituted by larger In ions $(0.80 \AA)$ [31,32]. Above results indicate that the detrimental $\left[2 \mathrm{Cu}_{\mathrm{Zn}}+\mathrm{Sn}_{\mathrm{Zn}}\right]$ defect cluster is reduced, which is partly responsible for the improvement of device performance.

To further explain the correlation between the diffusion mechanism and photovoltaic (PV) properties, the $C-V$ measurement was performed on Cell Reference and Cell Annealed\&Etched. Fig. S5 shows the $C-V$ scanning curves of Cell Reference and Cell Annealed\&Etched. The carrier density $\left(N_{\mathrm{A}}\right)$ of CZTSSe solar cells at the different bias is calculated by Equation (1):

$$
\begin{aligned}
& N_{\mathrm{A}}=\frac{2}{q S^{2} \varepsilon}\left[\frac{\mathrm{d}\left(1 / C^{2}\right)}{\mathrm{d} V}\right]^{-1}, \\
& w_{\mathrm{d}}=\frac{\varepsilon S}{C},
\end{aligned}
$$

where $w_{\mathrm{d}}$ is the depletion region width at the different bias calculated by Equation (2), $S$ is the total area of CZTSSe solar cells, $C$ is the capacitance at different bias, and $\mathcal{E}$ is the dielectric constant of CZTSSe absorber. Combining the $C-V$ measurement results shown in Fig. S5 and the calculation with Equations (1) and (2), plots of $N_{\mathrm{A}}$ versus the distance to the junction for Cell Reference and Cell Annealed\&Etched are obtained, as shown in Fig. 6. The $N_{\mathrm{A}}$ and $w_{\mathrm{d}}$ of Cell Reference and Cell Annealed\&Etched can be obtained when the $V$ is at $0 \mathrm{~V}$ 

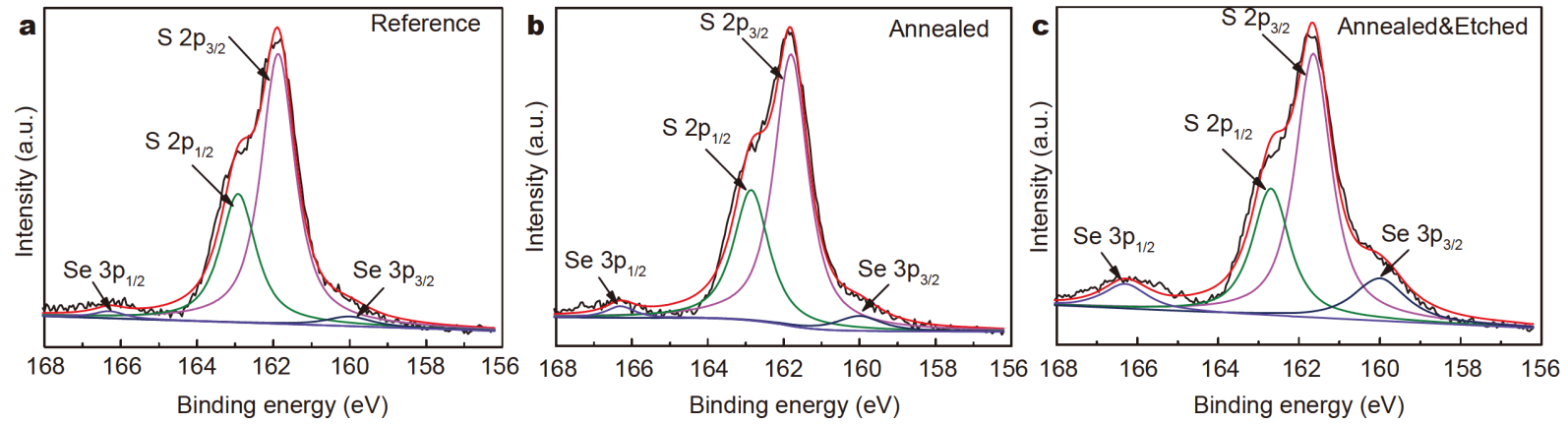

Figure 4 The S 2p/Se 3p XPS spectra of (a) Sample Reference, (b) Sample Annealed, and (c) Sample Annealed\&Etched (black line: spectra as measured; red line: spectra as fitted).

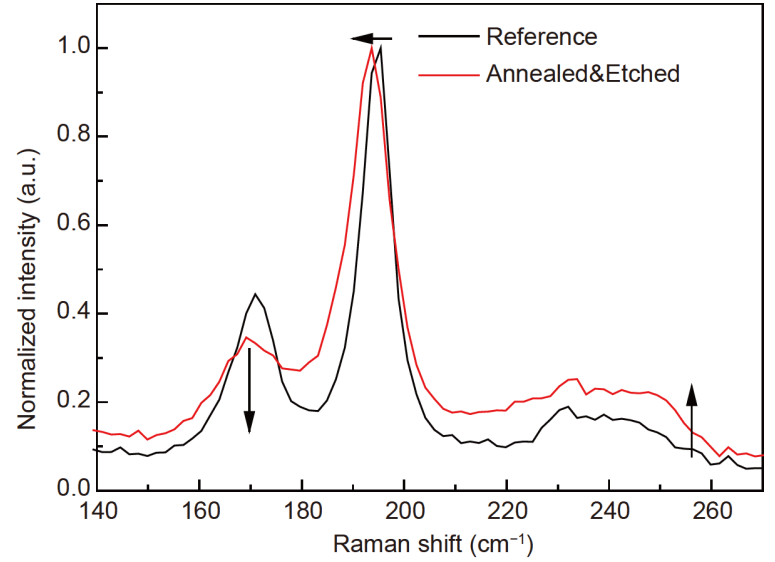

Figure 5 Raman spectra of Sample Reference and Sample Annealed\&Etched.

bias. From Fig. 6, with annealing and etching treatments, the $N_{\mathrm{A}}$ in the depletion region and interface increases from $3.17 \times 10^{15} \mathrm{~cm}^{-3}$ for the Sample Reference to $3.12 \times 10^{16} \mathrm{~cm}^{-3}$. Meanwhile, the $w_{\mathrm{d}}$ decreases from 200 to $145 \mathrm{~nm}$. The increase of $N_{\mathrm{A}}$ of Sample Annealed\&Etched is due to not only the suppression of interface recombination but also the indium diffusion into the CZTSSe absorber. As the Raman result indicates, the indium diffuses from $\mathrm{In}_{2} \mathrm{~S}_{3}$ into $\mathrm{Zn}(\mathrm{O}, \mathrm{S})$ and CZTSSe during the annealing treatment. As a consequence, $\mathrm{In}^{3+}$ replaces $\mathrm{Sn}^{4+}$ to form $\mathrm{In}_{\mathrm{Sn}}{ }^{-}$defects and then increases the $N_{\mathrm{A}}$ of the absorber. Simultaneously, $\mathrm{In}^{3+}$ substitutes $\mathrm{Zn}^{2+}$ to form $\operatorname{In}_{\mathrm{Zn}}{ }^{+}$defects and then increases the $N_{\mathrm{A}}$ of the $\mathrm{Zn}(\mathrm{O}, \mathrm{S})$ layer $[31,33]$. The effects of the increased carrier concentrations on the performances of CZTSSe solar cells have been simulated by wxAMPS. The set parameters of the simulation process are listed in Table S1. In accord with the $C-V$ results, the carrier concentrations of the CZTSSe layer of Sample Reference and Sample Annea-

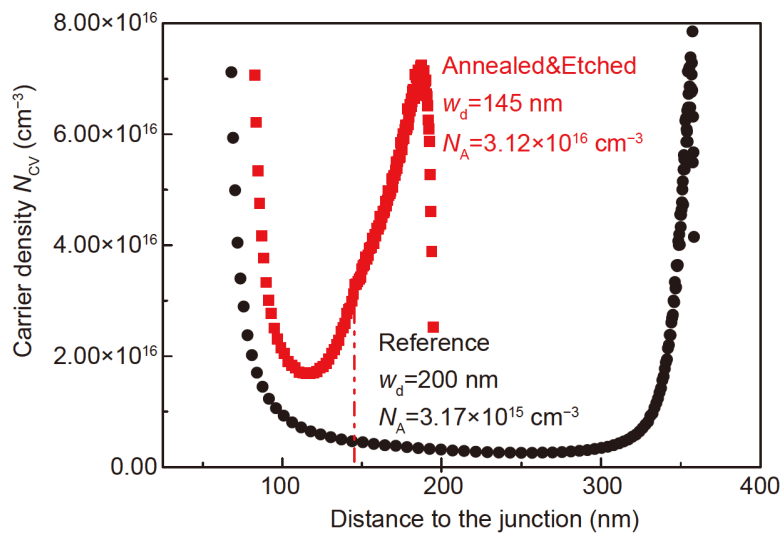

Figure 6 The carrier density profiles of Cell Reference and Cell Annealed\&Etched measured by $C-V$.

led\&Etched are set to $1 \times 10^{15}$ and $1 \times 10^{16} \mathrm{~cm}^{-3}$, respectively. From Ref. [33], the carrier concentration of the $\mathrm{Zn}(\mathrm{O}, \mathrm{S})$ layer of Sample Reference is set to $1 \times 10^{14} \mathrm{~cm}^{-3}$ and that of Sample Annealed\&Etched is set to $1 \times 10^{15} \mathrm{~cm}^{-3}$. The simulated energy band diagrams of Cell Reference and Cell Annealed\&Etched are shown in Fig. S6. From Fig. S6, the quasi-Fermi level of holes $\left(E_{\mathrm{fp}}\right)$ of Sample Annealed\&Etched moves toward valence band energy level $\left(E_{\mathrm{v}}\right)$ of the CZTSSe layer compared with that of Sample Reference, and the quasi-Fermi level of electronics $\left(E_{\mathrm{fn}}\right)$ of Sample Annealed\&Etched moves toward conduction band energy level $\left(E_{\mathrm{c}}\right)$ of the CZTSSe layer compared with that of Sample Reference. Therefore, the value of $E_{\mathrm{fn}}-E_{\mathrm{fp}}$ increases after the annealing and etching treatments. This result will facilitate the carrier separation, reduce the interface recombination, and lead to an improvement of the $V_{\mathrm{OC}}[28]$.

Fig. 7a presents the EQE responses of Cell Reference, Cell Annealed, and Cell Annealed\&Etched. This result is consistent with the $J-V$ data of these solar cells. The EQE 
response of Cell Annealed is enhanced in the wavelength region of 500-950 nm compared with Cell Reference. This is because the annealing process increases the builtin electric field strength across the $\mathrm{Zn}(\mathrm{O}, \mathrm{S}) / \mathrm{CZTSSe} \mathrm{p}-\mathrm{n}$ junction by inter-diffusion of the elements, and thus improves the carrier collection and $J_{\mathrm{SC}}$ (Fig. 7b, c). After etching treatment, the EQE response of Cell Anneale$\mathrm{d} \&$ Etched is enhanced throughout the whole wavelength region, which is due to not only the suppression of interface recombination but also the enhancement of light absorption by the increased surface roughness after the etching treatment (Fig. 1). As shown in the inset of Fig. 7a, the bandgaps of Cell Reference, Cell Annealed, and Cell Annealed\&Etched are determined from fits to the EQE data [34]. The bandgaps of these devices are almost unchanged after the treatments, in accordance with the bandgap of CZTSe in a previous report [28].

\section{The reason for the efficiency limitation of devices}

Based on the above discussion, it is promising to use $\mathrm{In}_{2} \mathrm{~S}_{3} / \mathrm{Zn}(\mathrm{O}, \mathrm{S})$ as the Cd-free hybrid buffer layer, and the annealing and ammonia etching treatments can be used to improve the performance of CZTSSe solar cells with the $\operatorname{In}_{2} \mathrm{~S}_{3} / \mathrm{Zn}(\mathrm{O}, \mathrm{S})$ buffer layer. However, the efficiency is still low compared with those of the reported Cd-free kesterite solar cell devices $[18,19]$. As shown in Table 1, the overall efficiency of these devices is mainly limited by low FF as a consequence of high $R_{\mathrm{S}}$ and high diode $A$.

To further reveal the reason for the low FF, a possible band alignment of the $\operatorname{In}_{2} \mathrm{~S}_{3} / \mathrm{Zn}(\mathrm{O}, \mathrm{S}) / \mathrm{CZTSSe}$ interface is shown in the schematic diagram in Fig. 8. As shown in
Table 1, the $A$ of these devices are all higher than 2.0, which indicates that there is serious recombination at the $\mathrm{In}_{2} \mathrm{~S}_{3} / \mathrm{Zn}(\mathrm{O}, \mathrm{S}) / \mathrm{CZTSSe}$ interface. Our group's previous report [19] indicated that a possible defect energy level $\left(E_{\mathrm{D}}\right)$ very close to the Fermi level aids the transport of the negative charges across the $\mathrm{Zn}(\mathrm{O}, \mathrm{S})$ layer even though a large conduction band spike exists at the $\mathrm{Zn}(\mathrm{O}, \mathrm{S}) /$ CZTSSe interface. This result indicates that there is no recombination at the $\mathrm{Zn}(\mathrm{O}, \mathrm{S}) / \mathrm{CZTSSe}$ interface. So the low FF may arise because a large barrier exists at the $\mathrm{In}_{2} \mathrm{~S}_{3} / \mathrm{Zn}(\mathrm{O}, \mathrm{S})$ interface [35]. The electron affinity $\left(\chi_{\mathrm{e}}\right)$ of $\mathrm{In}_{2} \mathrm{~S}_{3}$ is calculated according to Equation (3) [36]:

$E_{\mathrm{g}}=6.75-\chi_{\mathrm{e}}$.

The band gap energy $\left(E_{\mathrm{g}}\right)$ of $\mathrm{In}_{2} \mathrm{~S}_{3}$ is estimated to be $2.9 \mathrm{eV}$ from the transmittance and reflection spectra, as shown in Fig. S7. The calculated $\chi_{\mathrm{e}}$ of $\mathrm{In}_{2} \mathrm{~S}_{3}$ is $3.85 \mathrm{eV}$ according to Equation (3), and the $\chi_{\mathrm{e}}$ of CZTSSe is $4.35 \mathrm{eV}$ [28]. Based on the above results, the CBO of the $\mathrm{In}_{2} \mathrm{~S}_{3}$ and CZTSSe is $0.5 \mathrm{eV}$, and thus the band offset of $E_{\mathrm{D}}$ and $\mathrm{In}_{2} \mathrm{~S}_{3}$ is higher than $0.5 \mathrm{eV}$. The large band offset $(>0.4 \mathrm{eV})$ will lead to the abrupt decrease of FF. We used wxAMPS to simulate the effects of the band offset of $E_{\mathrm{D}}$ and $\operatorname{In}_{2} \mathrm{~S}_{3}$ on the performance of the $\operatorname{In}_{2} \mathrm{~S}_{3} / \mathrm{Zn}(\mathrm{O}, \mathrm{S}) /$ CZTSSe devices. The set parameters of the simulation process are listed in Table S2. It is found that as the bandgap of $\mathrm{In}_{2} \mathrm{~S}_{3}$ decreases from 2.9 to $2.7 \mathrm{eV}$ and $\chi_{\mathrm{e}}$ of $\mathrm{In}_{2} \mathrm{~S}_{3}$ increases from 3.85 to $4.05 \mathrm{eV}$, the band offset of $E_{\mathrm{D}}$ and $\mathrm{In}_{2} \mathrm{~S}_{3}$ is decreased and the $F F$ increases significantly with the other parameters unchanged (Table S3). This result indicates that the large band offset is a reason for
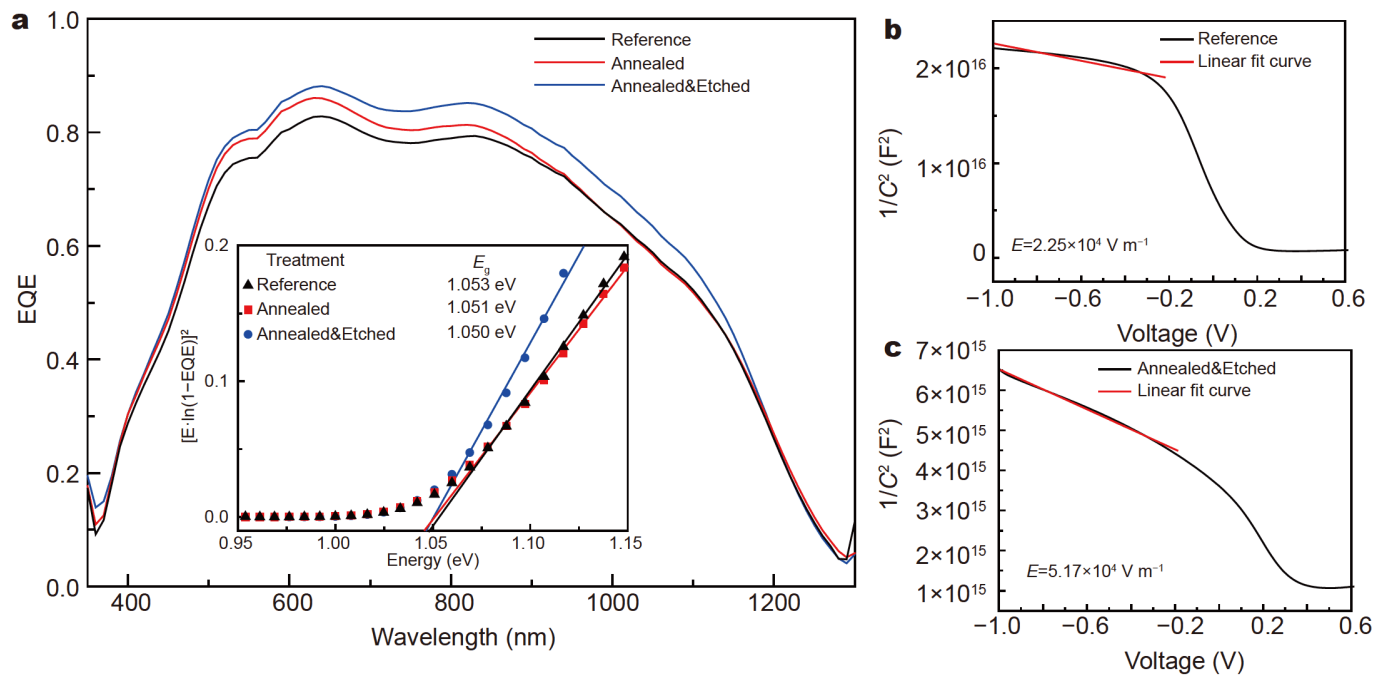

Figure 7 (a) The EQE responses of Cell Reference, Cell Annealed, and Cell Annealed\&Etched. Inset: the bandgaps of these devices from fitting with the EQE data. The built-in electric field strength of (b) Cell Reference and (c) Cell Annealed\&Etched estimated by $C-V$. 


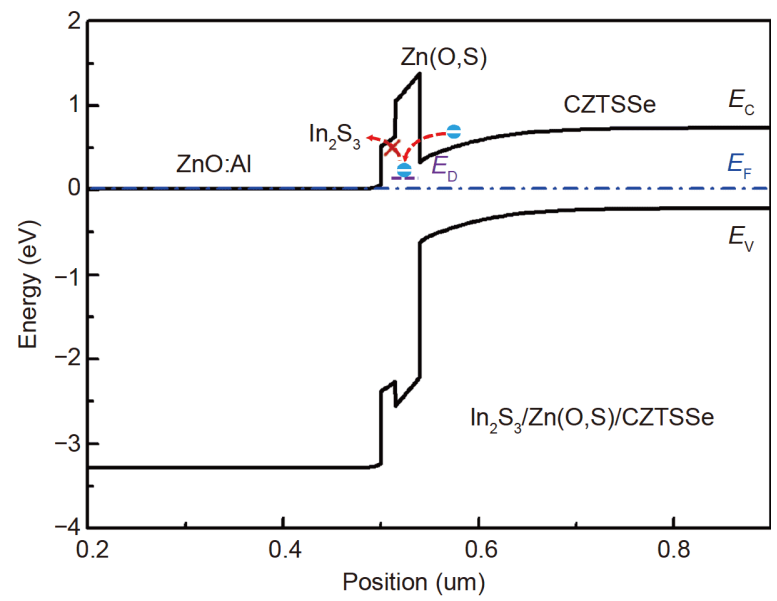

Figure 8 The schematic diagram of the band alignment of the $\mathrm{In}_{2} \mathrm{~S}_{3} /$ $\mathrm{Zn}(\mathrm{O}, \mathrm{S}) / \mathrm{CZTSSe}$ interface for devices.

the low FF, and the band offset can be decreased by decreasing the bandgap of the $\operatorname{In}_{2} \mathrm{~S}_{3}$ to improve the FF.

\section{CONCLUSIONS}

In conclusion, we developed CZTSSe solar cells with $\mathrm{In}_{2} \mathrm{~S}_{3} / \mathrm{Zn}(\mathrm{O}, \mathrm{S})$ hybrid buffer layers. The $\operatorname{In}_{2} \mathrm{~S}_{3}$ buffer layer was used to provide indium, which will diffuse into the $\mathrm{Zn}(\mathrm{O}, \mathrm{S}) / \mathrm{CZTSSe}$ layer via annealing. Further, the effect of annealing and ammonia etching treatments on the CZTSSe device performance was investigated. We find that the indium diffuses into the $\mathrm{Zn}(\mathrm{O}, \mathrm{S})$ forming $\mathrm{In}_{\mathrm{Zn}}{ }^{+}$as well as into the CZTSSe forming $\mathrm{In}_{\mathrm{Sn}}{ }^{-}$with annealing treatment, which increases the carrier concentrations of both the $\mathrm{Zn}(\mathrm{O}, \mathrm{S})$ and CZTSSe and increases the value of $E_{\mathrm{fn}}-E_{\mathrm{fp}}$. This facilitates the carrier separation and increases the built-in electric field strength, which leads to an increase of the $V_{\mathrm{OC}}$ and $J_{\mathrm{SC}}$. In addition, it is found that the ammonia etching treatment can reduce the interface recombination and enhance the absorption of light by increasing the surface roughness of the $\operatorname{In}_{2} \mathrm{~S}_{3}$ layer. Finally, the efficiency of the CZTSSe solar cell with sequential treatments is improved. Then, we use wxAMPS software to simulate the device performance. The simulation and experimental results reveal that a large band offset of $E_{\mathrm{D}}$ and $\mathrm{In}_{2} \mathrm{~S}_{3}$ is the physical origin of the low FF and efficiency, and the simulation also indicates that the FF and efficiency can be further improved by decreasing the bandgap of $\operatorname{In}_{2} \mathrm{~S}_{3}$. This study provides a new method to increase the carrier concentrations of absorber and buffer layers and also proposes a mean to further improve the efficiency of chalcopyrite solar cells with an $\operatorname{In}_{2} \mathrm{~S}_{3} /$ $\mathrm{Zn}(\mathrm{O}, \mathrm{S})$ buffer layer.
Received 6 May 2020; accepted 1 June 2020;

published online 27 September 2020

1 Mitzi DB, Gunawan O, Todorov TK, et al. Prospects and performance limitations for $\mathrm{Cu}-\mathrm{Zn}$-Sn-S-Se photovoltaic technology. Philos Trans R Soc A, 2013, 371: 20110432

2 Li J, Wang D, Li X, et al. Cation substitution in earth-abundant kesterite photovoltaic materials. Adv Sci, 2018, 5: 1700744

3 Wang D, Zhao W, Zhang Y, et al. Path towards high-efficient kesterite solar cells. J Energy Chem, 2018, 27: 1040-1053

4 Wang $\mathrm{D}, \mathrm{Wu} \mathrm{J}$, Liu $\mathrm{X}$, et al. Formation of the front-gradient bandgap in the Ag doped CZTSe thin films and solar cells. J Energy Chem, 2019, 35: 188-196

5 Wei J, Guo F, Wang $\mathrm{X}$, et al. $\mathrm{SnO}_{2}$-in-polymer matrix for highefficiency perovskite solar cells with improved reproducibility and stability. Adv Mater, 2018, 30: 1805153

6 Wang X, Cui Y, Li T, et al. Recent advances in the functional 2D photonic and optoelectronic devices. Adv Opt Mater, 2019, 7: 1801274

7 Yan C, Huang J, Sun $\mathrm{K}$, et al. $\mathrm{Cu}_{2} \mathrm{ZnSnS}_{4}$ solar cells with over $10 \%$ power conversion efficiency enabled by heterojunction heat treatment. Nat Energy, 2018, 3: 764-772

8 Taskesen T, Neerken J, Schoneberg J, et al. Device characteristics of an $11.4 \%$ CZTSe solar cell fabricated from sputtered precursors. Adv Energy Mater, 2018, 8: 1703295

9 Cabas-Vidani A, Haass SG, Andres C, et al. High-efficiency $\left(\mathrm{Li}_{x} \mathrm{Cu}_{1-x}\right)_{2} \mathrm{ZnSn}(\mathrm{S}, \mathrm{Se})_{4}$ kesterite solar cells with lithium alloying. Adv Energy Mater, 2018, 8: 1801191

10 Hiroi $\mathrm{H}$, Sakai N, Kato $\mathrm{T}$, et al. High voltage $\mathrm{Cu}_{2} \mathrm{ZnSnS}_{4}$ submodules by hybrid buffer layer. In: 39th IEEE Photovoltaic Specialists Conference. Tampa, 2013

11 Sakai N, Hiroi H, Sugimoto H. Development of Cd-free buffer layer for $\mathrm{Cu}_{2} \mathrm{ZnSnS}_{4}$ thin-film solar cells. In: 37th IEEE Photovoltaic Specialists Conference. Seattle, 2011

12 Klenk R, Steigert A, Rissom T, et al. Junction formation by $\mathrm{Zn}(\mathrm{O}, \mathrm{S})$ sputtering yields CIGSe-based cells with efficiencies exceeding 18\%. Prog Photovolt-Res Appl, 2014, 22: 161-165

13 Törndahl T, Platzer-Björkman C, Kessler J, et al. Atomic layer deposition of $\mathrm{Zn}_{1-x} \mathrm{Mg}_{x} \mathrm{O}$ buffer layers for $\mathrm{Cu}(\mathrm{In}, \mathrm{Ga}) \mathrm{Se}_{2}$ solar cells. Prog Photovolt-Res Appl, 2007, 15: 225-235

14 Kushiya K. Development of $\mathrm{Cu}\left(\mathrm{InGa}_{\mathrm{S}} \mathrm{Se}_{2}\right.$-based thin-film PV modules with a $\mathrm{Zn}(\mathrm{O}, \mathrm{S}, \mathrm{OH})_{x}$ buffer layer. Sol Energy, 2004, 77: 717-724

15 Lindahl J, Wätjen JT, Hultqvist A, et al. The effect of $\mathrm{Zn}_{1-x} \mathrm{Sn}_{x} \mathrm{O}_{y}$ buffer layer thickness in $18.0 \%$ efficient $\mathrm{Cd}$-free $\mathrm{Cu}(\mathrm{In}, \mathrm{Ga}) \mathrm{Se}_{2}$ solar cells. Prog Photovolt-Res Appl, 2013, 21: 1588-1597

16 Steirer KX, Garris RL, Li JV, et al. Co-solvent enhanced zinc oxysulfide buffer layers in kesterite copper zinc tin selenide solar cells. Phys Chem Chem Phys, 2015, 17: 15355-15364

17 Grenet L, Grondin P, Coumert K, et al. Experimental evidence of light soaking effect in $\mathrm{Cd}$-free $\mathrm{Cu}_{2} \mathrm{ZnSn}(\mathrm{S}, \mathrm{Se})_{4}$-based solar cells. Thin Solid Films, 2014, 564: 375-378

18 Neuschitzer M, Lienau K, Guc M, et al. Towards high performance Cd-free CZTSe solar cells with a $\mathrm{ZnS}(\mathrm{O}, \mathrm{OH})$ buffer layer: The influence of thiourea concentration on chemical bath deposition. J Phys D-Appl Phys, 2016, 49: 125602

19 Li J, Liu X, Liu W, et al. Restraining the band fluctuation of CBD$\mathrm{Zn}(\mathrm{O}, \mathrm{S})$ layer: Modifying the hetero-junction interface for high performance $\mathrm{Cu}_{2} \mathrm{ZnSnSe}_{4}$ solar cells with Cd-free buffer layer. Sol 
RRL, 2017, 1: 1700075

20 Dona JM, Herrero J. Chemical bath deposition of CdS thin films: An approach to the chemical mechanism through study of the film microstructure. J Electrochem Soc, 1997, 144: 4081

21 Grün M, Storzum A, Hetterich M, et al. Chlorine doping of cubic $\mathrm{CdS}$ and $\mathrm{ZnS}$ grown by compound source molecular-beam epitaxy. J Cryst Growth, 1999, 201-202: 457-460

22 Gao S, Zhang Y, Ao J, et al. Tailoring $\mathrm{Mo}(\mathrm{S}, \mathrm{Se})_{2}$ structure for high efficient $\mathrm{Cu}_{2} \mathrm{ZnSn}(\mathrm{S}, \mathrm{Se})_{4}$ solar cells. Sol Energy Mater Sol Cells, 2018, 176: 302-309

23 Bernède JC, Barreau N, Marsillac S, et al. Band alignment at $\beta$ $\mathrm{In}_{2} \mathrm{~S}_{3} /$ TCO interface. Appl Surf Sci, 2002, 195: 222-228

24 Bhira L, Essaidi H, Belgacem S, et al. Structural and photoelectrical properties of sprayed $\beta-\mathrm{In}_{2} \mathrm{~S}_{3}$ thin films. Phys Stat Sol A, 2000, 181: 427-435

25 Danilson M, Altosaar M, Kauk M, et al. XPS study of CZTSSe monograin powders. Thin Solid Films, 2011, 519: 7407-7411

26 Ji S, Shi T, Qiu X, et al. A route to phase controllable $\mathrm{Cu}_{2} \mathrm{ZnSn}$ $\left(\mathrm{S}_{1-x} \mathrm{Se}_{x}\right)_{4}$ nanocrystals with tunable energy bands. Sci Rep, 2013, 3: 2733

27 Ma R, Yang F, Li S, et al. Fabrication of $\mathrm{Cu}_{2} \mathrm{ZnSn}(\mathrm{S}, \mathrm{Se})_{4}$ (CZTSSe) absorber films based on solid-phase synthesis and blade coating processes. Appl Surf Sci, 2016, 368: 8-15

28 Li J, Kim SY, Nam D, et al. Tailoring the defects and carrier density for beyond 10\% efficient CZTSe thin film solar cells. Sol Energy Mater Sol Cells, 2017, 159: 447-455

29 Li J, Wang $\mathrm{H}$, Luo $\mathrm{M}$, et al. $10 \%$ Efficiency $\mathrm{Cu}_{2} \mathrm{ZnSn}(\mathrm{S}, \mathrm{Se})_{4}$ thin film solar cells fabricated by magnetron sputtering with enlarged depletion region width. Sol Energy Mater Sol Cells, 2016, 149: 242249

30 Li J, Zhang $\mathrm{Y}$, Wang $\mathrm{H}$, et al. On the growth process of $\mathrm{Cu}_{2} \mathrm{ZnSn}(\mathrm{S}$, $\mathrm{Se}_{4}$ absorber layer formed by selenizing $\mathrm{Cu}-\mathrm{ZnS}$-SnS precursors and its photovoltaic performance. Sol Energy Mater Sol Cells, 2015, 132: 363-371

31 Kim J, Hiroi H, Todorov TK, et al. High efficiency $\mathrm{Cu}_{2} \mathrm{ZnSn}(\mathrm{S}, \mathrm{Se})_{4}$ solar cells by applying a double $\operatorname{In}_{2} \mathrm{~S}_{3} / \mathrm{CdS}$ emitter. Adv Mater, 2014, 26: 7427-7431

32 Pei $\mathrm{Y}$, Guo J, Kou D, et al. Precise-tuning the In content to achieve high fill factor in hybrid buffer structured $\mathrm{Cu}_{2} \mathrm{ZnSn}(\mathrm{S}, \mathrm{Se})_{4}$ solar cells. Sol Energy, 2017, 148: 157-163

33 Jani M, Raval D, Pati RK, et al. Effect of annealing atmosphere on microstructure, optical and electronic properties of spraypyrolysed In-doped Zn(O,S) thin films. Bull Mater Sci, 2018, 41: 22

34 Denton AR, Ashcroft NW. Vegard's law. Phys Rev A, 1991, 43: 3161-3164

35 Huang TJ, Yin X, Qi G, et al. CZTS-based materials and interfaces and their effects on the performance of thin film solar cells. Phys Status Solidi RRL, 2014, 8: 735-762

36 Khoshsirat N, Md Yunus NA. Numerical analysis of $\operatorname{In}_{2} \mathrm{~S}_{3}$ layer thickness, band gap and doping density for effective performance of a CIGS solar cell using SCAPS. J Elec Materi, 2016, 45: 57215727

Acknowledgements This work was supported by the National Key R\&D Program of China (2019YFB1503500, 2018YFE0203400 and 2018YFB1500200), the National Natural Science Foundation of China (U1902218 and 11774187), and the 111 Project (B16027).

Author contributions Wang $\mathrm{S}$ designed the experiment and drafted the manuscript; Jiang Z, Shen Z, Sun Y and Guo H carried out the experiments for device fabrication, optimization and characterization; $\mathrm{Wu} \mathrm{L}$, Zhang J, Ao J and Wang $\mathrm{H}$ participated the design of experiment and the discussion of experimental results; Zhang Y supervised the whole project. All authors contributed to the general discussion.

Conflict of interest The authors declare that they have no conflict of interest.

\section{Supplementary information} online version of the paper.

Supporting data are available in the

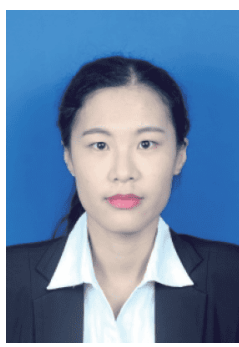

Siyu Wang received her BS degree in 2015 at the College of Computer Internet of Things Engineering, University of Hohai. Her research focuses on the fabrication of $\mathrm{Cu}_{2} \mathrm{ZnSn}(\mathrm{S}, \mathrm{Se})_{4}$ thin film solar cells.

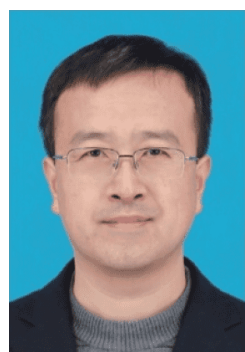

Yi Zhang is a professor in the Institute of Photoelectronic Thin Film Devices and Technology at Nankai University, China. Before he moved to Nankai University in 2008, he obtained his $\mathrm{PhD}$ degree in 2006 in condensed matter physics from the Institute of Physics, Chinese Academy of Sciences and then took 2-year postdoc in MaxPlanck Institute for Metals Research. The current focus of Zhang's group is investigating energyrelated materials and devices, like photovoltaic devices and photoluminescent materials for light-emitting diode (LED) applications.

\section{铜锌锡硫硒薄膜太阳电池中有希望的无镉双缓层}

王思宇 ${ }^{1}$, 姜振武 ${ }^{1}$, 申展 ${ }^{1}$, 孙亚利 ${ }^{1}$, 郭洪玲 ${ }^{1}$, 武莉 ${ }^{2}$, 张建军 ${ }^{1}$, 敖建平 ${ }^{1}$, 王海 ${ }^{3}$, 张效 ${ }^{1 *}$

摘要 $\mathrm{Zn}(\mathrm{O}, \mathrm{S})$ 薄膜由于低成本和生态友好的特性而被广泛用作锌 黄锡矿薄膜太阳能电池的无镉缓冲层. 但是 $\mathrm{Zn}(\mathrm{O}, \mathrm{S})$ 缓冲层的载流 子浓度和电导率较低, 这将会导致器件性能的降低. 在这项工作中, 我们引入了一层额外的 $\mathrm{In}_{2} \mathrm{~S}_{3}$ 缓冲层, 并通过后退火处理来改进 $\mathrm{Zn}(\mathrm{O}, \mathrm{S})$ 层以及CZTSSe层的属性. 经过退火处理后, 我们发现 $\mathrm{Zn}(\mathrm{O}$, S)和CZTSSe层的载流子浓度均增加, 这有助于载流子分离并增加 开路电压. 此外还发现, 氨水蚀刻处理可以去除污染物, 减少界面 缺陷, 并且增加 $\mathrm{In}_{2} \mathrm{~S}_{3}$ 层的表面粗粘度以用作减反层. 因此, 经过退 火和蚀刻处理后, CZTSSe太阳能电池的效率提高了 $24 \%$. 仿真和实 验结果表明, $\operatorname{In}_{2} \mathrm{~S}_{3}$ 层和 $\mathrm{Zn}(\mathrm{O}, \mathrm{S})$ 层中的缺陷能级之间较大的能带偏 移是限制CZTSSe器件的填充因子和效率的主要原因. 以上研究表 明 $\operatorname{In}_{2} \mathrm{~S}_{3} / \mathrm{Zn}(\mathrm{O}, \mathrm{S})$ 是一种有希望的高效锌黄锡矿太阳能电池的无镉 双缓冲层. 本研究还为通过铟掺杂提高吸收层和缓冲层的载流子 浓度提供了新的视角. 